fore reveal a great aptitude for the fine arts. Evenk pencil artists can be found in almost every settlement. The ancient Evenk art of embroidery is being revived too.

Recently the paper Soviet Evenkia, which is published in both the Russian and Evenk languages, together with the local broadcasting studio, the Evenk Scientific-research Institute of Language, Literature and History, and the local sociologists circulated a questionnaire among the inhabitants of the District. The answers they received testified to the change in the mentality of the Evenks.

Every inhabitant of the Area watches 42 films a year at an average, 868 papers and magazines are subscribed to by every thousand people; there are 15 books to every inhabitant at the state and collective farm libraries. The great Russian poet Alexander Pushkin (1799-1837) used to dream of the time when his works would be read by "the now wild Tungus". At present the Evenks read Pushkin both in Russian and their native language.

The chief occupations of the Evenks are, as before, hunting and reindeer-breeding. The Area is actually looked upon as the fur factory of the country. The sable, the polar fox and the squirrel are hunted and on the farms the silver fox, the mink and the muskrat are bred. An Evenk hunter or reindeer-breeder earns an average of 1,500 roubles a year (1 rouble amounts to $\$ 1.10$ ). In the settlements the Evenks live in wooden houses. The state gives 10 -year loans to those who build their own homes, and the sum is paid back in monthly instalments that amount to the price of a hunter's knife!

Many children from hunters' and reindeerbreeders' families spend their childhood in crèches and boarding-schools where they are completely provided for by the state. At the large educational institutions of the country, such as Moscow University, places are reserved specially for Evenk youth who can enter the institutes without having to compete.

In every Evenk settlement there is a hospital and a club with a cinema and library. If qualified medical assistance is required it is offered free of charge, and specialists fly out on planes from Tura to all parts of the Area.

The Evenks have their own representative in the Soviet parliament. He is Vasili Uvechan, a former hunter and shepherd who has received an education in Moscow and is now Master of Sciences (History) and the author of more than 30 works on the history of the peoples of the North. He speaks several foreign languages fluently.
The Evenk National Area has a great future before it; it is extremely rich in minerals. Under the basalt plateau lies the Tungus coal basin, which is the largest in the world. Its reserves are estimated in astronomical figures. There are also considerable reserves of non-ferrous metals, iron, salt, building materials and oil.

The graphite works, the first-born of Evenk industry, already produces casting graphite. The deposits of Iceland spar, which are also the largest in the world, are being developed. The northernmost hydro-electric power plant is being erected on the polar river of Khantaika. Surveying work is being conducted at present with a view to building two more hydro-electric power plants. One, the Nizhne-Tungusskaya, will have a capacity of 7 million kilowatts, while the Igarskaya will produce 5 million kilowatts. Both plants will supply electric power for developing industry.

Jean Katser

Novosti Press Agency

\section{Eskimo Bird Names at Chesterfield Inlet and Baker Lake, Keewatin, Northwest Territories}

The list below was compiled during a stay of about two months, 27 May to 21 July 1967, at Chesterfield Inlet and during a few days spent at Baker Lake in the course of the homeward journey. At Chesterfield Inlet my principal native informants on bird names were Krakok, a man about forty-five years old who had lived part of his earlier life at Daly Bay (about 50 miles further north) and a twelve-year-old boy Koluar, who early in his childhood had been brought from Iglulik to Chesterfield by his father and who often accompanied me on bird-watching walks. Koluar, through his father, had learnt some Iglulik versions of bird names but also knew those in use locally. The Baker Lake names were collected from a man about fifty years old, Kchlaiyuk, with one of his sons acting as interpreter.

According to Boas 1 these people belong to the tribe he called the Kinepitu or Agutit.

I conceive the principal virtue of the list here given to lie in the explanations of the hasic meaning of the native names for which I am indebted to the scholarship of Father E. Fafard, O.M.I. From the meanings of the bird names it will be evident that in the case of many only the context in which they are 
used would make it clear that a bird is referred to.

The names should be pronounced as if they were words in German with the proviso that $c h$ is always hard as in the Scots' word (of Gaelic origin) loch, or German Dach; the German sch sound is replaced by its simpler English equivalent $s h$, and $j$ is pronounced as in English jug.

This system of orthography was used to record Eskimo bird names from Banks Island in Manning et al. ${ }^{2}$ As far as I can determine it is essentially the same as that used by Porsild $^{3}$ for Mackenzie Delta Eskimo bird names and, judging from the Eskimo names given in Salomonsen's Birds of Greenland4, is also the same as that used for Eskimo words in general, in Greenland. Since Thibert's useful English-Eskimo dictionarys is based largely on work in the Keewatin region, it should be added that my orthography differs from his in the following points only: he writes as $k r$ the sound I would record as $k c h$, probably because there is no $c h$ sound in French; as $j$ here is to be pronounced as in English, $j$ and $y$ are not as with Thibert interchangeable in pronunciation; as both the $s$ and $s h$ sounds occur in Eskimo, both are consistently to be pronounced as defined above, in fact as they are sounded in English.

Snyder's Arctic Birds of Canada ${ }^{6}$ cites many Eskimo bird names in whatever orthography the original author happened to use but no explanations of the names are given. Lists of Eskimo bird names from areas fairly close to the one under consideration here, are that by Macpherson ${ }^{7}$ for Pelly Bay and the native names given by Sutton 8 for Southampton Island. Sutton included explanations of his names apparently based on what natives told him, but some of these explanations are undoubtedly erroneous.

It is worth noting that two of the bird names listed are used with a suffix as place names. Pituilaktok for Fairway Island S. E. of Chesterfield Inlet settlement, Akpatordjuark for Coats Island, and Akpatorardjuark for Walrus Island near Southampton Island. In all these instances the birds named, black guillemots and thick-billed murres respectively, nest on the particular island.

The material presented here was gathered in the course of a field trip undertaken to study the breeding behaviour of phalaropes, which was supported by grants from the National Research Council (Canada) and the Arctic Institute of North America.

\section{E. O. Höhn \\ Department of Physiology, University of Alberta, Edmonton, Alberta. \\ REFERENCES}

1Boas, F. 1888. The central Eskimo. Reprinted 1964 by University of Nebraska Press, Lincoln.

2Manning, T. H., E. O. Höhn and A. H. Macpherson. 1956. The birds of Banks Island. National Museum of Canada Bulletin No. 143, 144 pp.

3Porsild, A. E. 1943. Birds of the Mackenzie Delta. The Canadian Field Naturalist, 57: 19-35.

${ }^{4}$ Salomonsen, F. 1950. The birds of Greenland. English and Danish texts, Munksgaard, Copenhagen, 604 pp.

5Thibert, A. 1958. English-Eskimo, EskimoEnglish Dictionary. Ottawa: Research Centre of Amerindian Anthropology, University of Ottawa. 173 pp.

6Snyder, L. L. 1957. Arctic Birds of Canada. University of Toronto Press. $310 \mathrm{pp}$.

7Macpherson, A. H. 1958. Arviligjuarmiut names for birds and mammals. Arctic Circular, 9: 30-34.

8Sutton, G. M. 1932. The birds of Southampton Island. Memoirs of the Carnegie Museum, Pittsburgh, Vol. 12, part II, section 2, 275 pp.

9Jenness, D. 1944. Grammatical Notes on some Eskimo Dialects. Report of the Canadian Arctic Expedition, 1913-18. Vol. XV, Eskimo Language. Part B; Ottawa: King's Printer, 34 pp.

\section{English and Scientific Name}

Common and Yellow-billed loon,

Gavia, immer, Gavia adamsi

Arctic loon, Gavia arctica

Red throated loon, Gavia stellata

Whistling swan, Olor columbianus
Eskimo name at Chesterfield and

where different at Baker Lake $(B)$

tudlik

(B) Tuu'lik

kchaglulik

kchagsaukch

(B) kchagsaak

kudshiuk

(B) Kugyui
Explanatory Comments

Probably from the melodious spring

calls of both species

From the call taken as tcha

From the $k d k a k a$ spring call

From the call taken as ku (pronounced coo). 
English and Scientific Name

Canada goose,

Branta canadensis

Snow goose and blue goose Chen hyperborea and Chen caerulescens

Brant, Branta bernicla

White fronted goose, Anser albifrons

Pintail, Anas acuta

Green-winged teal, Anas carolinensis

Common goldeneye, Bucephala clangula

Oldsquaw, Clangula hyemalis

Common eider, Somateria mollissima
Eskimo name at Chester field and where different at Baker Lake $(B)$

neglerk or necklerk

(B) uluaralik

kanguk

nechlernak

(species not known at Baker Lake)

akto

(B) niglirvi

garshutok

kchomukchayuk
Explanatory Comments

Neglerk from the call taken as ne. Uluarulik the cheeked one, uluar cheek, in reference to the white cheek patch.

From the call taken as ka

Nak is a diminutive hence nechlernak means a small nechlerk

Akto $=$ the plump one. According to A. H. Macpherson at Pelly Bay this name is used for a large form of the Canada goose, ugluarulik being reserved for a small form of that species. Niglirvi, almost certainly from the call taken as nigli.

Garshutok = big lower lip. I fail to see how the birds appearance suggests this. Kchomukchayuk means jumps this. Kchomukchayuk means jumps
right-up i.e. in taking flight, in the right-up i.e. in taking fight, in the ducks. This second name was used by Koluar and his father and is apparently in use at Iglulik.

sarpak,

Meaning not known.

(B) native name not known to informant.

kabvirtok

kabvirtok = big head, an appropriately named feature of ducks of this genus.

agiadshuk

(B) a'lier

Both names mean, tries to say $a$, in reference to the male's spring call: a äonwa (using German phonetics).

mitivik or mitshek

male = amaulik

Mitek is a generic term for duck, mitivik means big duck; amaulik, has an amaut, the male in breeding plumage suggests a white amaut worn on a black background. (See Figs. 1 and 2).

kingalik or kchingalik

The one with the nose, kchinga $=$ nose, refers to the fleshy nob above the base of the male's bill.

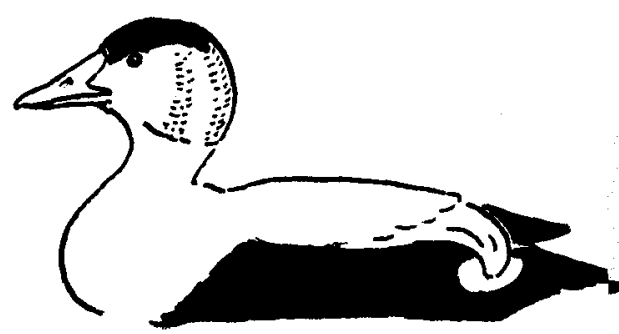

FIG. 1. Male common eider duck suggests a white amaut worn over black.

FIG. 2. Chesterfield Inlet woman wearing the amaut.

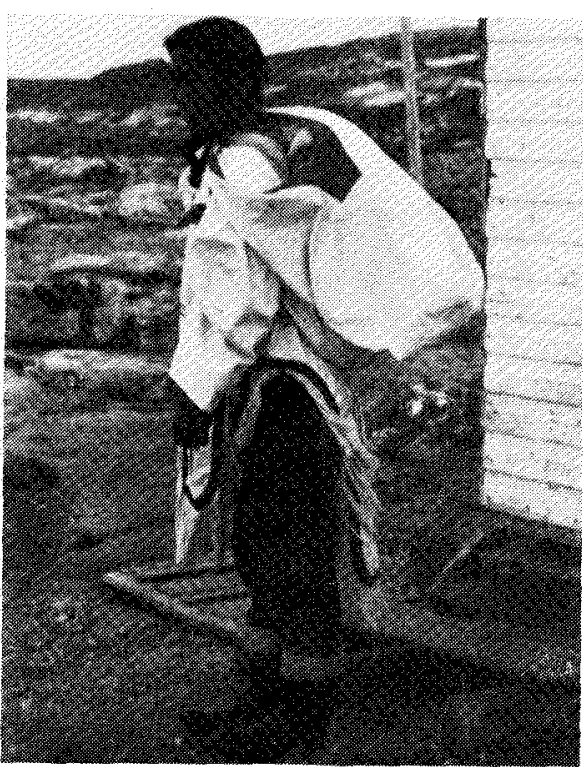




\section{English and Scientific Name}

Red-breasted merganser, Mergus serrator

Eskimo name at Chesterfield and where different at Baker Lake $(B)$

pitiulayurak

(B) nuyaglek

Gyrfalcon,
Falce rusticolus

Peregrine falcon, Falco peregrinus

Rough-legged hawk, Buteo lagopus

Eagle, Aquila

Willow ptarmigan, Lagopus lagopus kigavik

(B) kchigiavik

kigaviaktshuk

(B) kchigiaviagyuk

kchayok

(B) Kchinguayu

naktoalik

achigivik

(B) achiglivik
Rock ptarmigan, Lagopus mutus

Sandhill crane,

Grus canadensis

Semipalmated plover.

Charadrius semipalmatus

Golden plover

Pluvialis dominica

Black-bellied plover,

Squatarola squatarola

Ruddy turnstone,

Arenaria interpres

Whimbrel,

Numenius phalaropus

Sandpipers in general

Dunlin,

Calidris alpina achigik,

(B) achigiak

tatigak

(B) tatigia

kchollichulli

tulli' iuk

(B) tullik

Tulli'iuk

(B) kergleyauch

taliguak

(B) kchaliguak

shiuktuvuk

(B) name not known to my informant

sigiareaktshuk

(B) tuituak

shigiareaktok

(B) aiverkchea

\section{Explanatory Comments}

Like the pitiula or black guillemot. The overall appearance of the birds in flight is similar to the extent that both look dark above with partly white wings.

Nuyaglek = (the one who) has hair on his head, an evident reference to the mane-like crest of both sexes of this mane-1ik.

The grasper

The small grasper, tshuk and kyuk are diminutives.

kchayok = brown; kchinguayu = (the one who is) always complaining. Probably referring to the screeching call which descends in pitch.

Has claws.

Achigivik $=$ the real achigik, see below. Achigik, achigiak or other below. Achigik, achigiak or other
variants on this name appear to be variants on this name appear to be
forms of a word coined specifically for ptarmigan, an important bird to virtually all Eskimo, in whose territories one or other of 2 species is common. Furthermore, it seems that the commonest of the 2 species in any one area is called achigik (or a variant of that name) whereas the other, locally that name) whereas the other, locally
rarer species, is given a name which rarer species, is given a name which modifies the name of the commoner Banks Island where the willow ptarmigan predominates, it is called agkilak in the Delta ${ }^{z}$ and achigik on Banks $^{2}$ The rarer rock ptarmigan in the Delta is called niksaktugak - the the Delta is called niksaktugak - the belcher - from the throaty rrrp spring
call of the male; on Banks Island it is called achigik niksatualuk - the belching achigik. In the Chesterfield area to distinguish the willow ptarmigan from the rock ptarmigan which is the common species, the name given to the mon species, the name given to the
former is achigivik. Vik is a suffix former is achigivik. Vik is a suffix denoting the real or genuine
name theans the ptarmigan. The suffix livik is either a variant of vik or luavik, the latter according to Thibert ${ }^{5}$ also means the real, genuine.

The long one, takiyok = long, referring to the bird's long-necked and longlegged appearance.

Probably from the alarm call taken as kcholli.

From the alarm call taken as tulli or tullik.

Probably in imitation of the commonest call täui (in German phonetics).

Meaning uncertain. Sutton ${ }^{8}$ explains the Southampton Island equivalent teliviatsuk as teli being an imitation of its battle cry.

From the call taken as shiu.

Small long-beaked one.

Tui caller.

Large (tok) long beaked one. Referring to the long decurved bill which is to the long decurved bill which is Lake name, aiverk = walrus. 
Red phalarope

Phalaropus fulicarius

Pomarine jaeger,

Stercorarius pomarinus

Parasitic and long-tailed

jaeger, Stercorarius

parasiticus and $S$. longicaudus

Glaucous gull,

Larus hyperboreus

Herring gull,

Larus argentatus

Sabines gull,

Xema Sabini

Arctic tern

Sterna paradisaea

Black guillemot,

Thick-billed murre,

Uria lomvia

Snowy owl

Nyctea scandiaca

Short-eared owl,

Asia flammeus

Raven

Corvus corax

Water pipit

Anthus spinoletta

Horned lark,

Eremophila alpestris
Eskimo name at Chesterfield and where different at Baker Lake (B)

savrak

ishungaktshok

(B) ichungaktshok

ishunga

nauyavak

wauyak

(B) nauya

irrigareaktshuk

(B) ichigagliuk

imerkotailak

Pitiula

(B) bird not known there.

akpat or akpak

ukpik

ukpiguach

(B) mahelik

tulugak

inguiaitok

tulliyuyoch

siutilik

(B) pudshioktuk

Common and Hoary redpoll, Acanthis flammea and $A$. hornemanni

Savannah sparrow, Passerculus sandwichensis

Lapland longspur,

Calcarius lapponicus

uvingniak

kuyamertak

Krenerktak mannuilitalik

(B) tingmiagluk

kaluktok

male = amauligak

\section{Explanatory Comments}

Probably a corruption from the Western e.g. Mackenzie Delta form of it name, aukshuak, auk = blood referring to the bird's colour. The word savrak has no meaning.

Large (tshok) ishunga.

Large-winged. For their body size the two smaller species of jaeger are in fact rather large-winged birds.

$\mathrm{Nau}=$ where $\mathrm{vak}=$ usually. Hence the one who asks where, or the searcher (for food).

See above.

The irri caller, irri is quite a good rendering of its spring call. Ichigagliuk probably refers to the same call rendered as ichi.

Goes at the water many times, immer = water, referring to the plunging of the bird into the water to hunt small fish.

Fast off the nest, when disturbed.

Refers to the fast flight of this alcid cf. akpattok = steps, walks, runs.

Wide open eyes.

The swooping ukpik, referring to the bird's manner of flight. Mahelik = has something like the gills of a fish in evident reference to the facial disk.

Pecks many times.

(The one who) won't sit down, or sit still.

Small tullik or golden plover, siutilik means the one who has something like means the one who has something like head.

Probably again a reference to the horns for Thibert ${ }^{5}$ gives puyaluk for ear wax.

The whistler, referring to the bird's song.

Meaning not known.

The one with black spots, the bibbed one, both names refer to the male's black head and throat. Tingmiagluk small bird, tingmiak $=$ bird

Kaluktok meaning not known, amauligak, has an amaut. The male's breeding plumage suggests a black amaut, with the hood down, worn on a white body. (See Fig. 3)

Small land bird (generic term) kopanuar

FIG. 3. Male snow bunting in breeding plumage; suggests a black amaut (with the hood turned down) worn on white.

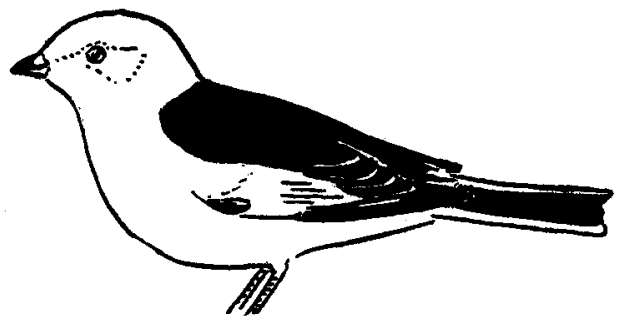

